\title{
MOLECULAR AND SEROTYPING CHARACTERIZATION OF NON- SHIGA TOXIGENIC ESCHERICHIA COLI ASSOCIATED WITH FOOD COLLECTED FROM THE LOCAL MARKET IN FAYOUM GOVERNORATE, EGYPT
}

\author{
Amr E. M. Mahmoud ${ }^{1}$, Ghada O. El-demerdash ${ }^{2}$, Mohamed H. H. Roby ${ }^{3}$ \\ and Sahar R. Mohamed ${ }^{2}$ \\ ${ }^{1}$ Biochemistry Department, Faculty of Agriculture, Fayoum University, \\ Fayoum, Egypt. \\ ${ }^{2}$ Animal Health Research Institute, Dokki, Giza, Egypt. \\ ${ }^{3}$ Food Science and Technology Department, Faculty of Agriculture, Fayoum \\ University, Fayoum, Egypt.
}

\begin{abstract}
:
Escherichia coli is considered as one of the bacteria that causing diarrhea outbreaks all over the world, and it is responsible for diseases for human and animals as well

A total number of 50 raw milk and 50 raw beef meat samples were collected from the local market in Fayoum Governorate. These samples were subjected for bacteriological, serological and molecular investigations. E. coli was isolated from raw milk and raw beef samples with an isolation rate of $58 \%$ and $14 \%$, respectively.

Serogrouping of the $E$. coli isolates from the raw milk samples revealed presence of $\mathrm{O}_{142}, \mathrm{O}_{55}, \mathrm{O}_{111}, \mathrm{O}_{27}$, and $\mathrm{O}_{26}$ with percentage of $20.69 \%, 20.69 \%, 17.24 \%, 17.24 \%$, and $3.45 \%$, respectively. However, the serogrouping of the $E$. coli isolates from raw beef meat samples revealed presence of $\mathrm{O}_{111}, \mathrm{O}_{27}, \mathrm{O}_{142}, \mathrm{O}_{55}$, and $\mathrm{O}_{127}$ with percentage of $28.56 \%, 14.28 \%, 14.28 \%, 14.28 \%$, and $14.28 \%$, respectively.

Multiplex PCR was applied for the detection of virulence genes including shiga-toxin genes (stxl and stx2), and the intimin gene (eae) which detected in E. coli. All the isolates were negative to both stxl and st $x 2$ genes. Meanwhile, the raw milk isolates of $\mathrm{O}_{142}, \mathrm{O}_{55}, \mathrm{O}_{111}$, and $\mathrm{O}_{27}$ were positive to eae gene. However, $\mathrm{O}_{26}$ isolate was negative to this gene. Also, the raw beef meat isolates of $\mathrm{O}_{142}, \mathrm{O}_{55}, \mathrm{O}_{111}$, and $\mathrm{O}_{27}$ were positive to eae gene. But, $\mathrm{O}_{127}$ isolate was negative to this gene.
\end{abstract}

KEY WORDS: E. coli, Virulence genes, Raw milk and Raw meat.

\section{INTRODUCTION}

Diarrhea is the second cause of death after pneumonia in children aged between 1 to 59 months, with mortality number of 0.509 million per year worldwide. Developing countries had the majority of this mentioned mortality cases of children by diarrhea (Liu et al., 2016 and WHO, 2017). Diarrhea outbreaks are happening all over the world which has the attention as an

Fayoum J. Agric. Res. \& Dev., Vol. 33, No.1, January, 2019 
Amr E. M. Mahmoud', et al.,

important public health problem that caused by Escherichia coli bacteria causing diseases for human and animals as well (Buchholz et al., 2011; Watson et al., 2017 and Valilis et al., 2018). This Gram-negative bacteria exists as part of the normal flora of animals and humans' gastrointestinal tract and responsible for infection between both of them (Karmali et al., 2010 and Lim et al., 2010). The Majority of its strains are harmless. Unfortunately, there are many virulence factors such as the mobile genetic elements including; bacteriophages, plasmids....etc and pathogenicity islands that may be acquired by these strains resulting in turning them to the pathogenic state (Kaper et al., 2004). Moreover, most of E. coli carrying hosts are apparently healthy and asymptomatic (Hussein and Bollinger 2005, and Bogitsh et al., 2018). And, ruminants such as sheep, goats and especially cattle, are counted as the main reservoir of E. coli bacteria (Kaper et al., 2004). E. coli transmission route starts when the bacteria could pass into the food chain via any contaminated food, drinks and water with feces (Suardana et al., 2017). So, E. coli transmission may occur via the consumption of any contaminated type of uncooked meat, fruits, vegetables, unpasteurized milk and its products (Karmali et al., 2010 and Tzschoppe et al., 2012). Consequently, E. coli infection may lead to many food-borne diseases in human including, diarrhea, renal failure, brain failure and hemolytic uremic syndrome which considered as life-threatening disease (Karmali et al., 2010 and Lim et al., 2010). There are six pathotypes of this bacterium, enterotoxigenic E. coli \{ETEC\}, enteropathogenic $E$. coli $\{\mathrm{EPEC}\}$, enteroaggregative $E$. coli $\{\mathrm{EAEC}$, diffusely adherent $E$. coli $\{$ DAEC $\}$ enterohemorrhagic $E$. coli $\{$ EHEC $\}$, and enteroinvasive E. coli \{EIEC\} (Nataro and Kaper 1998, and Lei et al., 2018). Also, there are many strains of $E$. coli that produce toxins called "shiga toxins" which cause illness in the vertebrates. These strains are called "shigatoxin producing" E. coli (STEC) or verocytotoxic E. coli which are the pathotype group of enterohemorrhagic $E$. coli $\{$ EHEC $\}$ (Nguyen and Sperandio 2012; Lacher et al., 2016, and Valilis et al., 2018). Also, it is classified by its serotypes which include more than 700 serotypes according to their $\mathrm{O}$ and $\mathrm{H}$ antigen (Lacher et al., 2016 and Bai et al., 2018). E. coli O157:H7 is the major serotype that was associated with human illness world widely. This strain was classified as the most common strain responsible of the E. coli outbreaks in the USA, German, Northern Ireland, South Korea, Japan, England, Scotland and many other countries (Tarr et al., 2005; Money et al., 2010; Buchholz et al., 2011; Dallman et al., 2012; Park et al., 2014; Watahiki et al., 2014; Launders et al., 2016; Saeedi et al., 2017 and Yang et al., 2017). However, in the last twenty years the non-O157 stains were classified as responsible serotypes for 20 to $50 \%$ of the E. coli associated illness' outbreaks world widely, these serotypes are including the $\mathrm{O}_{26}, \mathrm{O}_{45}$, $\mathrm{O}_{103}, \mathrm{O}_{111}, \mathrm{O}_{121}$ and $\mathrm{O}_{145}$ (Wasilenko et al., 2012; Gould et al., 2013; Fayoum J. Agric. Res. \& Dev., Vol. 33, No.1, January, 2019 
MOLECULAR AND SEROTYPING CHARACTERIZATION OF ....... 116 Albonico et al., 2017 and Balamurugan et al., 2017). Chapman et al., (2006), found that there were more than 50 virulence factors of $E$. coli participated in its pathogenicity. E. coli bacteria produce many factors associated with human illness such as Shiga toxins (stx 1 and stx2), besides the other virulence factors that responsible for the attachment of the bacteria to the hosts' intestinal epithelial cells. This attaching lesions caused by the intimin protein that encoded by the eae gene (Chapman et al., 2006; Farfan and Torres 2012; and Gharieb et al., 2015). So, the main aim of this work is to detect the virulence genes stxl, stx2 and eae of Escherichia coli bacteria growing in raw milk and beef meat collected from the local market in Fayoum Governorate. Besides, characterizing the serotypes of the Escherichia coli isolates.

\section{MATERIALS AND METHODS}

\section{Sample collection}

A total number of 50 raw milk and 50 raw beef meat samples were collected from the local market in Fayoum Governorate. Samples were collected in sterile marked container then inoculated in Carry and Blair transport medium. The last was kept in ice box for the laboratory bacterial culturing and identification.

\section{Bacteriological examination}

The collected samples were cultured using MacConkey agar. The plates were aerobically incubated up to two days at $37^{\circ} \mathrm{C}$. Then the suspected colonies were picked up and tested for Gram's reaction. The positive colonies were identified biochemically by using Vitek2 compact system (bioMérieux, Durham, NC, USA), according to the manufacturer's instructions (Chatzigeorgiou et al., 2011 and Quinn et al., 2011), using the GramNegative (GN) card which is a complete system for routine identification testing of most clinically significant Gram-Negative organisms. Colonies were transferred to the $0.45 \%$ saline to prepare the organism suspension with a density equivalent to a 0.50 to 0.63 McFarland using a calibrated VITEK® 2 DensiCHEK $^{\mathrm{TM}}$ Plus. Then, the last suspension used to fill the test cards for Vitek2 instrument.

Serological identification

Escherichia coli isolates were serologically identified using the rapid diagnostic E. coli antisera set (Denka sieken comp. LTD) according to Edwards and Ewing (1972).

Molecular examination

DNA extraction

Escherichia coli isolates' DNA extraction was done using the QIAamp DNA Mini kit (Qiagen, Germany, GmbH) with modifications from the manufacturer's recommendations and according to (Sambrook et

Fayoum J. Agric. Res. \& Dev., Vol. 33, No.1, January, 2019 
al., 1989). In brief, a $200 \mu \mathrm{l}$ of the each sample suspension was added to the proteinase $\mathrm{K}$ solution $(10 \mu 1), 200 \mu \mathrm{l}$ of the lysis buffer and incubated at $56^{\circ} \mathrm{C}$ for $10 \mathrm{~min}$. Then, $200 \mu \mathrm{l}$ of $100 \%$ ethyl alcohol was added to the lysate. After washing and centrifuging the sample, $100 \mu 1$ of elution buffer that provided by the kit was used to elute the nucleic acid.

\section{PCR amplification}

PCR amplification of the E. coli isolates' DNA of the virulent genes was carried out using the primers that revealed to (stxl, stx2, and eae) genes as indicated in (Table1). This PCR amplification was applied on 10 random isolates (one of each serotype) of $E$. coli, 5 of each raw milk and beef meat samples for the detection of the virulence genes. The PCR amplification of these primers were utilized in a $25 \mu \mathrm{l}$ reaction containing $12.5 \mu \mathrm{l}$ of PCR Master Mix (Takara, Japan), $1 \mu \mathrm{l}$ of each primer of 20 pmol concentration, 6 $\mu l$ of DNA template and $4.5 \mu \mathrm{l}$ of nuclease-free water. The reaction was performed in an (Applied Biosystem Thermal Cycler). Cycling conditions were used as recommended by the manufacturer as follow: primary denaturation: $94^{\circ} \mathrm{C} / 5 \mathrm{~min}$., secondary denaturation: $94^{\circ} \mathrm{C} / 30 \mathrm{sec}$., annealing: $55^{\circ} \mathrm{C} / 45$ sec., extension: $72^{\circ} \mathrm{C} / 45$ sec., no. of cycles: 35 and final extension: $72^{\circ} \mathrm{C} / 10 \mathrm{~min}$.

\section{Analysis of the PCR Products}

$1.5 \%$ agarose gel (Applichem, Germany, $\mathrm{GmbH}$ ) was used to separate the PCR products by electrophoresis in $1 \mathrm{x}$ TBE buffer at room temperature using gradients of $5 \mathrm{~V} / \mathrm{cm}$. For gel analysis, $20 \mu \mathrm{l}$ of the PCR products was loaded in each gel well. The fragments sizes were determined using a gelpilot 100bp plus DNA Ladders (Qiagen, Germany, $\mathrm{GmbH}$ ). The gel was photographed by a gel documentation system (Alpha Innotech, Biometra).

Table (1): Primers used for the detection of virulent genes of $E$. coli, F: Forward and R: Reverse.

\begin{tabular}{|c|c|c|c|}
\hline $\begin{array}{c}\text { Target } \\
\text { Genes }\end{array}$ & Primers sequences & $\begin{array}{c}\text { Amplified } \\
\text { Segment (bp) }\end{array}$ & Reference \\
\hline \multirow{2}{*}{ eae } & F: ATG CTT AGT GCT GGT TTA GG & 248 & \multirow{2}{*}{ Bisi-Johnson et al., 2011 } \\
\cline { 2 - 3 } & R: GCC TTC ATC ATT TCG CTT TC & & Shetty et al., 2012 \\
\hline \multirow{2}{*}{ stx1 } & F:ACACTGGATGATCTCAGTGG & 614 & Shetty et al., 2012 \\
\cline { 2 - 3 } & R:CTGAATCCCCCTCCATTATG & & \\
\hline \multirow{2}{*}{ stx2 } & F:CCATGACAACGGACAGCAGTT & 779 & \\
\cline { 2 - 3 } & R:CCTGTCAACTGAGCAGCACTTTG & & \\
\hline
\end{tabular}

Fayoum J. Agric. Res. \& Dev., Vol. 33, No.1, January, 2019 
MOLECULAR AND SEROTYPING CHARACTERIZATION OF 118

RESULTS

The results of bacteriological examination

Out of the 100 raw milk and meat samples collected from the local market in Fayoum Governorate, Egypt, the E. coli was isolated as (58\%) of the raw milk samples followed by (14\%) of the raw beef meat samples as shown in table (2). Also, the biochemical identification of the positive E. coli isolates by Vitek2 system is shown in table (3).

Table (2): Prevalence of $E$. coli bacteria isolated from collected samples.

\begin{tabular}{|c|c|c|}
\hline \multirow{2}{*}{$\begin{array}{c}\text { No. of examined } \\
\text { Samples }\end{array}$} & \multicolumn{2}{|c|}{ Escherichia coli } \\
\cline { 2 - 3 } & No. of +ve samples & \% of +ve samples \\
\hline 50 raw milk samples & 29 & 58 \\
\hline 50 raw beef meat samples & 7 & 14 \\
\hline
\end{tabular}

No.: Number of positive isolates of $E$. coli and \%: Percentage in relation to No. of examined samples (50).

Table (3): Biochemical details of Escherichia coli using Vitek 2 compact system.

\begin{tabular}{|c|c|c|c|c|c|c|c|c|c|c|c|c|c|c|c|c|c|}
\hline \multicolumn{10}{|c|}{ Table 3: Biochemical details of Escherichia coli } \\
\hline 2 & APPA & - & 3 & ADO & - & 4 & PyrA & - & 5 & IARL & - & 7 & dCEL & - & 9 & BGAL & + \\
\hline 10 & H2S & - & 11 & BNAG & - & 12 & AGLTP & - & 13 & dGLU & + & 14 & GGT & - & 15 & OFF & + \\
\hline 17 & BGLU & - & 18 & dMAL & + & 19 & dMAN & + & 20 & dMNE & + & 21 & BXYL & - & 22 & BAlap & - \\
\hline 23 & proA & - & 26 & LIP & - & 27 & PLE & - & 29 & TyrA & - & 31 & URE & - & 32 & dSOR & + \\
\hline 33 & SAC & - & 34 & dTAG & - & 35 & dTER & + & 36 & CIT & - & 37 & MNT & - & 39 & $5 \mathrm{KG}$ & + \\
\hline 40 & ILATK & - & 41 & AGLU & - & 42 & SUCT & + & 43 & NAGA & - & 44 & AGAL & - & 45 & PHOS & - \\
\hline 46 & GlyA & - & 47 & ODC & + & 48 & LDC & + & 53 & IHISa & - & 56 & CMT & + & 57 & BGUR & - \\
\hline 58 & O129R & + & 59 & GGAA & - & 61 & IMLTa & - & 62 & ELLM & - & 64 & ILATa & - & & & \\
\hline
\end{tabular}

**Vitek2 Gram-negative card well contents according to BioMerieux, manufacturer manual are indicted in Appendix 1.

The results of serotyping of $E$. coli positive isolates

Serogrouping of the $29 \mathrm{E}$. coli isolates from raw milk samples revealed presence of $\mathrm{O}_{142}, \mathrm{O}_{55}, \mathrm{O}_{111}, \mathrm{O}_{27}$, and $\mathrm{O}_{26}$ with percentage of $20.69 \%, 20.69 \%$, $17.24 \%, 17.24 \%$, and $3.45 \%$, respectively. Also, there were 6 isolates untyped as shown in table (4). However, the serogrouping of the $7 \mathrm{E}$. coli isolates from raw beef meat samples revealed presence of $\mathrm{O}_{111}, \mathrm{O}_{27}, \mathrm{O}_{142}, \mathrm{O}_{55}$, and $\mathrm{O}_{127}$ with percentage of $28.56 \%, 14.28 \%, 14.28 \%, 14.28 \%$, and $14.28 \%$, respectively. Besides, there was one isolate untyped as shown in table (4).

Fayoum J. Agric. Res. \& Dev., Vol. 33, No.1, January, 2019 
Amr E. M. Mahmoud ${ }^{1}$, et al.,

Table (4): Serotyping of $E$. coli isolates of both raw milk and beef meat samples.

\begin{tabular}{|c|c|c|c|c|}
\hline \multirow{2}{*}{$\begin{array}{c}\text { E. coli } \\
\text { serotypes }\end{array}$} & \multicolumn{2}{|c|}{ Raw milk samples } & \multicolumn{2}{c|}{ Raw beef meat samples } \\
\cline { 2 - 5 } & $\begin{array}{c}\text { No. of tested } \\
\text { strain (29) }\end{array}$ & $\begin{array}{c}\text { \% of } \\
\text { serotypes }\end{array}$ & $\begin{array}{c}\text { No. of tested } \\
\text { strain (7) }\end{array}$ & \% of serotypes \\
\hline $\mathrm{O}_{142}$ & 6 & 20.69 & 1 & 14.28 \\
\hline $\mathrm{O}_{55}$ & 6 & 20.69 & 1 & 14.28 \\
\hline $\mathrm{O}_{111}$ & 5 & 17.24 & 2 & 28.56 \\
\hline $\mathrm{O}_{27}$ & 5 & 17.24 & 1 & 14.28 \\
\hline $\mathrm{O}_{26}$ & 1 & 03.45 & ---- & ------ \\
\hline $\mathrm{O}_{127}$ & -------- & 1 & 14.28 \\
\hline Untyped & 6 & 20.69 & 1 & 14.28 \\
\hline
\end{tabular}

No.: Number of isolates and \%: Percentage in relation to No. of tested isolated strains of $E$. coli which is 29 for raw milk samples and 7 for raw meat samples.

\section{The results of molecular identification of the virulence genes of $E$. coli} isolates

PCR amplification was applied on 10 random isolates (one of each serotype) of E. coli, 5 of each raw milk and beef meat samples for the detection of the virulence genes. All the isolates were negative to both the shiga-toxin genes (stxl) and (stx2) (Figure 1). Meanwhile, the raw milk isolates of $\mathrm{O}_{142}, \mathrm{O}_{55}, \mathrm{O}_{111}$, and $\mathrm{O}_{27}$ were positive to the intimin gene (eae). However, $\mathrm{O}_{26}$ isolate was negative to eae gene of E. coli (Figure 2). Also, the raw beef meat isolates of $\mathrm{O}_{142}, \mathrm{O}_{55}, \mathrm{O}_{111}$, and $\mathrm{O}_{27}$ were positive to the eae gene. But, $\mathrm{O}_{127}$ isolate was negative to eae gene of $E$. coli (Figure 2).

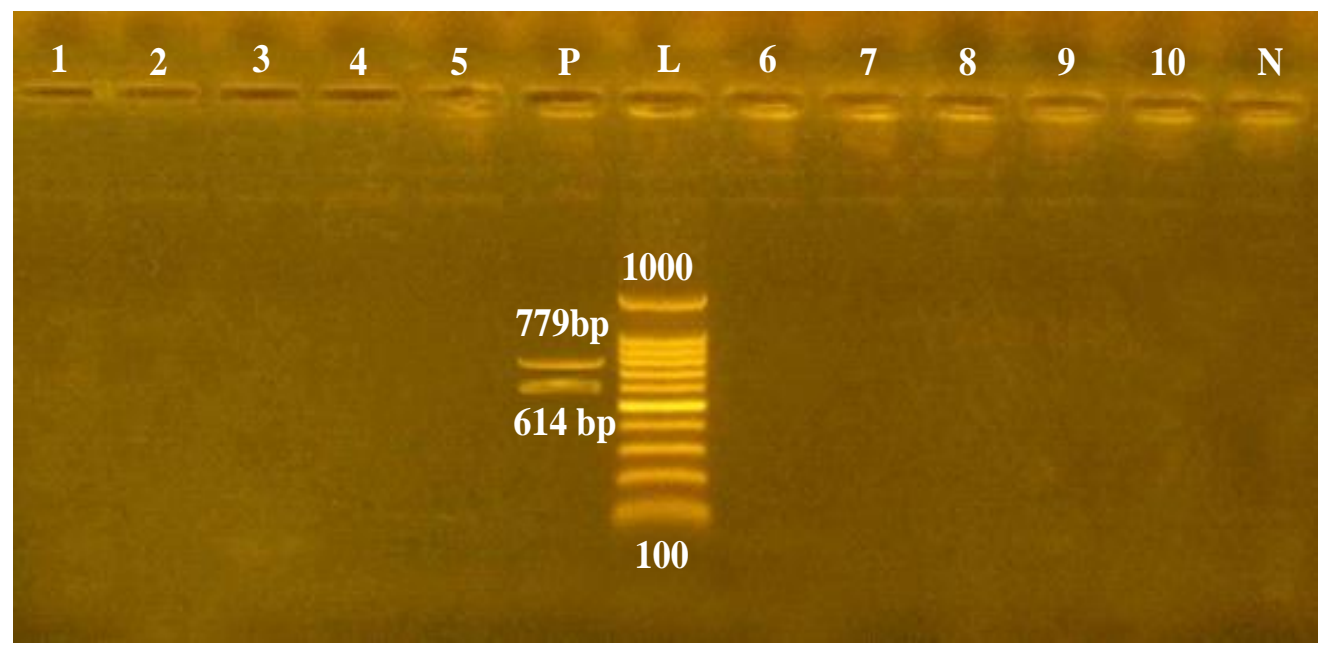

Fig (1): Agar gel electrophoresis showed results of multiplex PCR for detection of (stxl which amplified at $614 \mathrm{bp}$ and stx2 which amplified at

Fayoum J. Agric. Res. \& Dev., Vol. 33, No.1, January, 2019 
MOLECULAR AND SEROTYPING CHARACTERIZATION OF 120 $779 \mathrm{bp}$ ), L: represents the molecular size marker (100pb plus ladder), N: Negative control, P: Positive control, Lanes from 1:5 represent the raw milk isolates $\mathrm{O}_{142}, \mathrm{O}_{55}, \mathrm{O}_{111}, \mathrm{O}_{27}$, and $\mathrm{O}_{26}$ which are negative for both stx 1 and stx2 genes, and Lanes from 6:10 represent the raw beef meat isolates $\mathrm{O}_{142}, \mathrm{O}_{55}$, $\mathrm{O}_{111}, \mathrm{O}_{27}$, and $\mathrm{O}_{127}$ which are negative for both stx 1 and stx 2 genes.

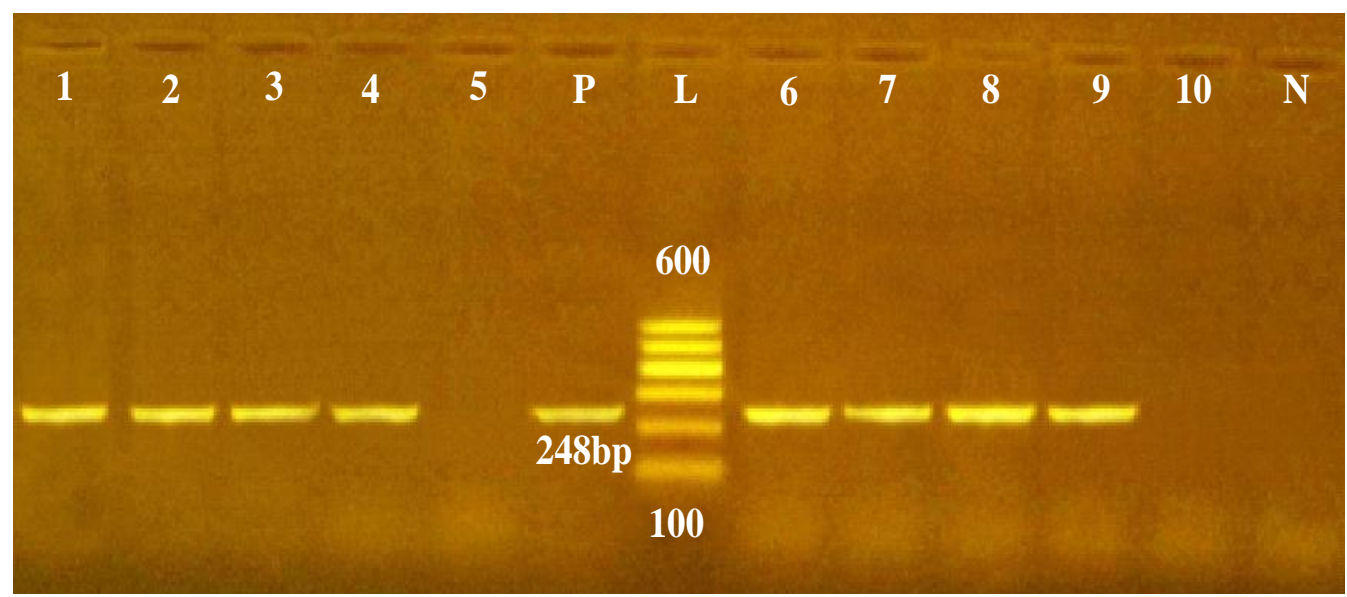

Fig (2): Agarose gel electrophoresis showed results of Multiplex PCR for detection of eae gene, L: represents the molecular size marker (100pb plus ladder), N: Negative control, P: Positive control of eae gene (248bp), Lanes from 1:5 represents the raw milk isolates; Lanes 1:4 are the isolates of $\mathrm{O}_{142}$, $\mathrm{O}_{55}, \mathrm{O}_{111}$, and $\mathrm{O}_{27}$ which are positive for eae gene, Lane 5 is the $\mathrm{O}_{26}$ isolate which is negative for the eae gene, Lanes from 6:10 represent the raw beef meat isolates; Lanes 6:9 are the isolates of $\mathrm{O}_{142}, \mathrm{O}_{55}, \mathrm{O}_{111}$, and $\mathrm{O}_{27}$ which are positive for eae gene, lane 10 is the $\mathrm{O}_{127}$ isolate which is negative for the eae gene.

\section{DISCUSSION}

Escherichia coli considered as one of the bacteria that causing diarrhea outbreaks all over the world, and it is responsible for diseases for human and animals as well (Buchholz et al., 2011: Watson et al., 2017 and Valilis et al., 2018). Unfortunately, the developing countries had the majority of mortality cases of children aged from 1 to 59 months caused by diarrhea (Liu et al., 2016 and WHO, 2017). Also, neonatal calf diarrhea is considered as of the most important health problems in livestock causing high economic losses worldwide either directly due to mortality and needs for treatment or indirectly through poor growth (El-Seedy et al., 2016; Abebaw et al., 2018 and Bokma et al., 2019).

In present study, E. coli was isolated from raw milk samples with an isolation rate of $58 \%$. This result was lower than the isolation rate that

Fayoum J. Agric. Res. \& Dev., Vol. 33, No.1, January, 2019 
described by (Ombarak $\boldsymbol{e t}$ al., (2016), who isolated $E$. coli with an incidence of $76.4 \%$. But, this result was higher than the isolation rate that described by (Metwally and Ali (2015); Bedasa et al., 2018 and Singh et al., 2018), who isolated $E$. coli with an incidence of $44 \%, 32 \%$ and $17.19 \%$ respectively. However, this percentage was almost similar to the rate that obtained by El Nahas et al., (2015), who isolated E. coli with an incidence of 55\%. There were only $7 \mathrm{E}$. coli isolates out of the 50 raw meat samples with an isolation rate of $14 \%$. This percentage was almost similar to the rate that obtained by Bedasa et al., (2018). However, this result was higher than the rates described by Rahimi et al., (2012) and Moawad et al., (2017), who isolated E. coli with an incidence of $8.2 \%$ and $11.7 \%$, respectively. This high rate may be explained by that transmission of infection occurs during the milking process by milkers' hands, contaminated equipments and milking machine Scherrer $\boldsymbol{e t}$ al., (2004). Also, this may be the same in case of meat rates which is more likely as cause of poor hygienic measures and customs during slaughter, handling, transportation and even during all stages of storage Rahimi $\boldsymbol{e t}$ al., (2010). Also, contamination level may be varied due to the differences in geographic or national region, processing environments, meat sources and the methodologies which the samples were taken such as; the samples amount, numbers and even the periods of which the samples were tested Kegode $\boldsymbol{e t}$ al., (2008).

Serogrouping of $E$. coli isolates from the raw milk samples revealed presence of $\mathrm{O}_{142}, \mathrm{O}_{55}, \mathrm{O}_{111}, \mathrm{O}_{27}$, and $\mathrm{O}_{26}$ with percentage of $20.69 \%, 20.69 \%$, $17.24 \%, 17.24 \%$, and $3.45 \%$, respectively. Also, the serogrouping of E. coli isolates from raw meat samples revealed presence of $\mathrm{O}_{111}, \mathrm{O}_{27}, \mathrm{O}_{142}, \mathrm{O}_{55}$, and $\mathrm{O}_{127}$ with percentage of $28.56 \%, 14.28 \%, 14.28 \%, 14.28 \%$, and $14.28 \%$, respectively. The above mentioned results are in agreement with results of Aisha (2001), who isolated $\mathrm{O}_{26}, \mathrm{O}_{127}$ and $\mathrm{O}_{27}$, Correa and Marin (2002), who isolated $\mathrm{O}_{26}, \mathrm{O}_{55}, \mathrm{O}_{111}, \mathrm{O}_{127}$ and $\mathrm{O}_{142}$, Blanco et al., (2006), who isolated $\mathrm{O}_{55}, \mathrm{O}_{111}, \mathrm{O}_{127}$ and $\mathrm{O}_{142}$, Lin et al., (2011) who isolated $\mathrm{O}_{26}, \mathrm{O}_{142}$ and $\mathrm{O}_{111}$, Fadel et al., (2017), who isolated $\mathrm{O}_{26}, \mathrm{O}_{27}, \mathrm{O}_{55}, \mathrm{O}_{111}$, and $\mathrm{O}_{142}$, and Kalule et al., (2018), who isolated $\mathrm{O}_{26}, \mathrm{O}_{55}$, and $\mathrm{O}_{111}$,

Molecular characterization of the $E$. coli isolates from both raw milk and beef meat samples through applying different conditions of multiplex PCR for detection of genes encoding virulence factors (stx1, stx 2 and eae). All the isolates were negative to both the shiga-toxin genes (stxl) and (stx2) (Figure 1). Meanwhile, the raw milk isolates of $\mathrm{O}_{27}, \mathrm{O}_{55}, \mathrm{O}_{111}$, and $\mathrm{O}_{142}$ were positive to the intimin gene (eae). These results agreed with the results of Blanco et al., (2006) who found that $\mathrm{O}_{55}, \mathrm{O}_{111}$ and $\mathrm{O}_{142}$ are negative for both shiga-toxin genes (stxl) and (stx2) and positive to the intimin gene (eae). However, $\mathrm{O}_{26}$ isolate was negative to gene (eae) of E. coli (Figure 2). This result is in

Fayoum J. Agric. Res. \& Dev., Vol. 33, No.1, January, 2019 
MOLECULAR AND SEROTYPING CHARACTERIZATION OF. 122 agreement with the results of Correa and Marin (2002), who found that $\mathrm{O}_{26}$ is negative for the (eae) gene. Also, the raw meat isolates of $\mathrm{O}_{142}, \mathrm{O}_{55}, \mathrm{O}_{111}$, and $\mathrm{O}_{27}$ were positive to the intimin gene (eae). But, $\mathrm{O}_{127}$ isolate was negative to gene (eae) of E. coli (Figure 2). These results agreed with Blanco et al., (2006) except for the $\mathrm{O}_{127}$ isolate, which was found to be positive for eae gene. These differences in expressing some genes for the same serotype may be because the ability of some strains to acquire many virulence factors (Kaper et al., 2004). Also, Correa and Marin (2002) found that some $\mathrm{O}_{55}$ strains are negative for the (eae) gene and other $\mathrm{O}_{55}$ strains are positive for the same gene. And, Sanchez et al., (2010) found that $\mathrm{O}_{127}$ was negative to eae and stxl genes but it was positive to stx 2 gene. And, some serotypes were found to express specific genes and the same serotype are not, like the E. coli serotype of $\mathrm{O}_{157}$ some isolates expressed both stx2 and eae genes, some expressed only eae gene and others were negative to eae gene and positive to stx2 gene.

\section{CONCLUSION}

E. coli was found in both raw milk and raw beef meat in Fayoum local market. And, the molecular characterization of its virulence genes indicated that all the isolates are missing the shiga-toxin genes (stxl and stx2). However, most of the detected $E$. coli serotypes were found to have the eae virulence gene, which still needs more attention because the ability of some strains to acquire many virulence factors and may all the isolates of this study have other virulent factors that were not examined in this study. More important, the serotypes of $\mathrm{O}_{26}$ and $\mathrm{O}_{111}$ which were isolated in this study are classified as a part of the main non-O157 stains that responsible for 20 to $50 \%$ of the E. coli associated illness' outbreaks world widely. So, strict hygienic measures and intensive care should be applied by the authorities and all the people to overcome this kind of contamination for good health for human and animals and consequently to minimize the economic losses.

\section{REFERENCES}

Abebaw, R.; Mitku, F. and Fentie, T. (2018): A review on the importance of calf diarrhea in dairy production system: Ethiopian perspective. J. Am. Sci., 14(10): 71-83.

Aisha, R. A. (2001): Comparative studies on diarrhea caused By E. coli in farm animals. J. Egypt. Vet. Med. Assoc., 61 (6): 39-49.

Albonico, F.; Gusmara, C.; Gugliotta, T.; Loiacono, M.; Mortarino, M. and Zecconi, A (2017): A new integrated approach to analyze bulk tank milk and raw milk filters for the presence of the E. coli serogroups frequently associated with VTEC status. Res. Vet. Sci., 115: 401-406.

Bai, X.; Mernelius, S.; Jernberg, C.; Einemo, I. M.; Monecke, S.; Ehricht, R.; Lofgren, S. and Matussek, A. (2018): Shiga toxin-producing Escherichia coli infection in Jönköping county, Sweden: occurrence and molecular

Fayoum J. Agric. Res. \& Dev., Vol. 33, No.1, January, 2019 
Amr E. M. Mahmoud ${ }^{1}$, et al.,

characteristics in correlation with clinical symptoms and duration of stx

shedding. Front. Cell. Infect. Microbiol., 8:125. doi: 10.3389/fcimb.2018.00125.

Balamurugan, S.; Ahmed, R.; Gao, A. and Strange, P. (2017): Comparison of the fate of the top six non-O157 shiga-toxin producing Escherichia coli (STEC) and E. coli O157:H7 during the manufacture of dry fermented sausages. Int. J. Food Microbiol., 259: 14-21.

Bedasa, S.; Shiferaw, D.; Abraha, A. and Moges, T. (2018): Occurrence and antimicrobial susceptibility profile of Escherichia coli O157:H7 from food of animal origin in Bishoftu town, Central Ethiopia. Int. J. Food Contam., $5(2): 1-8$.

Bisi-Johnson, M. A.; Obi, C. L.; Vasaikar, S. D.; Baba, K. A. and Hattori, T. (2011): Molecular basis of virulence in clinical isolates of Escherichia coli and Salmonella species from a tertiary hospital in the Eastern Cape, South Africa. Gut Pathogens, 3 (9): 1-8.

Blanco, M.; Blanco,J. Dahbi, G.; Mora,A.; Alonso, M. P.; Varela, G.; Gadea,M. P.; Schelotto,F.; Gonza, E. A. and Blanco, J. (2006): Typing of intimin (eae) genes from enteropathogenic Escherichia coli (EPEC) isolated from children with diarrhoea in Montevideo, Uruguay: identification of two novel intimin variants (mB and jR/b2B). J. Med. Microbiol., 55: 11651174.

Bogitsh, B. J.; Carter, C. E. and Oeltmann, T. N. (2018): Human parasitology, $5^{\text {th }}$ ed.; Elsevier, London, United Kingdom.

Bokma, J.; Boone, R.; Deprez, P. and Pardon, B. (2019): Risk factors for antimicrobial use in veal calves and the association with mortality. $J$. Dairy Sci., 102: 607-618.

Buchholz, U.; Bernard, H.; Werber, D.; Böhmer, M.; Remschmidt, C.; Wilking, H.; Deleré, Y.; Heiden, M.; Adlhoch, M.; Dreesman, J. and Ehlers, J. (2011): German outbreak of Escherichia coli O104:H4 associated with sprouts. N. Engl. J. Med., 365: 1763-1770.

Chapman, T. A.; Wu, X. Y.; Barchia, I.; Bettelheim, K. A.; Driesen, S.; Trott, D.; Wilson, M. and Chin, J. J. (2006): Comparison of virulence gene profiles of Escherichia coli strains isolated from healthy and diarrheic swine. Appl. Environ. Microbiol., 72: 4782-4795.

Chatzigeorgiou, K. S.; Sergentanis, T. N.; Tsiodras, S.; Hamodrakas, S. J. and Bagos, P.G., (2011): Phoenix 100 versus Vitek 2 in the identification of gram-positive and gram-negative bacteria: a comprehensive meta-analysis. J. clin. microbiol.,49: 3284-3329.

Correa, M. G. P. and Marin, J. M. (2002): O-serogroups, eae gene and EAF plasmid in Escherichia coli isolates from cases of bovine mastitis in Brazil. Vet. Microbiol., 85: 125-132.

Dallman, T.; Smith, G. P.; O'brien, B.; Chattaway, M. A.; Finlay, D., Grant, K. A. and Jenkins, C. (2012): Characterization of a verocytotoxin producing enteroaggregative Escherichia coli serogroup O111:H21 strain

Fayoum J. Agric. Res. \& Dev., Vol. 33, No.1, January, 2019 
associated with a household outbreak in Northern Ireland. J. Clin. Microbiol., 50: 4116-4119.

Edwards, P. R. and Ewing, W. H. (1972): Identification of Enterobacteriacae, $3^{\text {rd }}$ ed., Burgess Pub. Co., MN, USA.

El Nahas, A. W.; Mohamed, H. A.; El Barbary, H. A. and Mohamed, H. S. (2015): Incidence of E. coli in raw milk and its products. Benha Vet. Med. J., 29 (1): 112-117.

El-Seedy, F. R.; Abed, A. H.; Yanni, H. A. and Abd El-Rahman, S. A. A. (2016): Prevalence of E. coli and Salmonella in neonatal calves with diarrhea. $J$. Basic and Applied Sci. Cell. Mol. Bio. 62: 21-28. .

Fadel, H. M.; Afifi, R. and Al-Qabili, D. M. (2017): Characterization and zoonotic impact of Shiga toxin producing Escherichia coli in some wild bird species. Vet. World, 10 (9): 1118-1128.

Farfan, M. J. and Torres, A. G., (2012): Molecular mechanisms that mediate colonization of Shiga toxin-producing Escherichia coli strains. Infect. Immun., 80: 903-913.

Gharieb, R. M.; Fawzi, E. M.; Attia, N. E. and Bayoumi, Y. H. (2015): Calf diarrhea in Sharkia province, Egypt: diagnosis; prevalence, virulence profiles and zoonotic potential of the causative bacterial agents. Int. J. Agric. Sci. Vet. Med., 3 (2): 71-87.

Gould, L. H.; Mody, R. K.; Ong, K. L.; Clogher, P.; Cronquist, A. B.; Garman, K. N.; Lathrop, S.; Medus, C.; Spina, N. L.; Webb, T. H.; White, P. L.; Wymore, K.; Gierke, R. E.; Mahon, B. E.; Griffin, F.T. ( 2013): Increased recognition of non-O157 shiga toxin-producing Escherichia coli infections in the United States during 2000-2010: epidemiologic features and comparison with E. coli O157 infections. Foodborne Pathog. Dis., 10; 453-460.

Hussein, H. S. and Bollinger, L. M. (2005): Prevalence of Shiga toxin-producing Escherichia coli in beef cattle. J. Food Prot., 68: 2224-2241.

Kalule, J. B.; Keddy, K. H. and Nicol, M. P. (2018): Characterisation of STEC and other diarrheic E. coli isolated on CHROM agarTM STEC at a tertiary referral hospital, Cape Town. BMC Microbiol., 18 (55): 1-8.

Kaper, J. B.; Nataro, J. P. and Mobley, H. L. (2004): Pathogenic Escherichia coli. Nat. Rev. Microbiol., 2: 123-140.

Karmali, M. A.; Gannon, V. and Sargeant, J. M. (2010): Verocytotoxinproducing Escherichia coli (VTEC), Vet. Microbiol., 140 (3-4): 360-370.

Kegode, R. B.; Doetkott, D. K.; Khaitsa, M. L. and Wesley, I. V. (2008): Occurrence of Campylobacter species, Salmonella species and generic Escherichia coli in meat products from retail outlets in the Fargo metropolitan area. J. Food Safety, 28: 111-125.

Lacher, D. W.; Gangiredla, J.; Patel, I.; Elkins, C. A. and Feng, P. C.H. (2016): Use of the Escherichia coli identification microarray for characterizing the health risks of Shiga toxin-producing E. coli isolated from foods. J. Food Prot., 79: 1656-1662.

Fayoum J. Agric. Res. \& Dev., Vol. 33, No.1, January, 2019 
Amr E. M. Mahmoud ${ }^{1}$, et al.,

Launders, N.; Locking, M. E.; Hanson, M.; Willshaw, G.; Charlett, A.; Salmon, R.; Cowden, J. and Adak, G. K. (2016): A large Great Britainwide outbreak of STEC O157 phage type 8 linked to handling of raw leeks and potatoes. Epidemiol. Infect., 144: 171-181.

Lei, L.; Rehman, M. U.; Huang, S.; Zhang, L.; Wang, L.; Mehmood, K.; Zhang, H.; Tong, X.; Wang, M. and Li, J. (2018): Antimicrobial resistance and prevalence of diarrheagenic Escherichia coli (DEC), in diarrheic yaks of Tibetan Plateau, China. Acta Trop., 182: 111-114.

Lim, J. Y.; Yoon, J. W. and Hovde, C. J. (2010): A brief overview of Escherichia coli O157:H7 and its plasmid O157. J. Microbiol. Biotechnol., 20 (1): 514.

Lin, A.; Nguyen, L.; Lee, T.; Clotilde, L. M.; Kase, J. A.; Son, I.; Carter, J. M. and Lauzon, C. R. (2011): Rapid $O$ serogrouping of the ten most clinically relevant STECs by Luminexmicrobead-based suspension array. J Microbiol. Methods, 87 (1): 105-110.

Liu, L.; Oza, S.; Hogan, D.; Chu, Y.; Perin, J.; Zhu, j.; Lawn, j. E.; Cousens, S.; Mathers, C. and Black, R. E. (2016): Global, regional, and national causes of under-5 mortality in 2000-15: an updated systematic analysis with implications for the Sustainable Development Goals. Lancet, 388: 3027-3035.

Metwally, A. M. M. and Ali, F. H. M. (2015): Escherichia coli $\mathrm{O}_{157}$ in dairy products from retailers and small dairy shops. J. Food and Dairy Sci., Mansoura Univ., 6 (5): 349-355.

Moawad, A. A.; Hotzel, H.; Awad, O.; Tomaso, H.; Neubauer, H.; Hafez, H. M. and El-Adawy, H. (2017): Occurrence of Salmonella entericaand Escherichia coli in raw chicken and beef meat in northern Egypt and dissemination of their antibiotic resistance markers. Gut Path., 9 (57): 113.

Money, P.; Kelly, A. F.; Gould, S. W. J.; Denholm-Price, J.; Threlfall, E. J. and Fielder, M. D. (2010): Cattle, weather and water: mapping Escherichia coli O157:H7 infections in humans in England and Scotland. Environ. Microbiol., 12: 2633-2644.

Nataro, J. P. and Kaper, J. B. (1998): Diarrheagenic Escherichia coli. Clin. Microbiol. Rev., 11: 132-201.

Nguyen, Y. and Sperandio, V. (2012): Enterohemorrhagic E. coli (EHEC) pathogenesis. Front. Cell. Infect. Microbiol., 2:90. doi: 10.3389/fcimb.2012.00090.

Ombarak, R. A.; Hinenoya, A.; Awasthi, S. P.; Iguchi, A.; Shima, A.; Elbagory, R. M. and Yamasaki, S. (2016): Prevalence and pathogenic potential of Escherichia coli isolates from raw milk and raw milk cheese in Egypt. Int. J. Food Microbiol., 221: 69-76.

Park, J. H.; Oh, S. S.; Oh, K. H.; Shin, J.; Jang, E. J.; Jun, B. Y.; Youn, S. K. and Cho, S. H. (2014): Diarrheal outbreak caused by atypical enteropathogenic Escherichia coli O157:H45 in South Korea. Foodborne Pathog. Dis., 11: 775-781.

Fayoum J. Agric. Res. \& Dev., Vol. 33, No.1, January, 2019 
MOLECULAR AND SEROTYPING CHARACTERIZATION OF .

Quinn, P. J.; Markey, B. K.; Leonard, F. C.; Hartigan, P.; Fanning, S. and Fitzpatric, E. S. (2011): Veterinary microbiology and microbial diseases. $2^{\text {nd }}$ edition. Willy-Blackwell publisher, IN, USA.

Rahimi, E.; Ameri, M. and Kazemeini, H. R. (2010): Prevalence and antimicrobial resistance of Campylobacter species isolated from raw camel, beef, lamb and goat meat in Iran. Foodborne Path. Dis., 7; 443-447.

Rahimi, E.; Kazemeini, H. R. and Salajegheh, M. (2012): Escherichia coli O157:H7/NM prevalence in raw beef, camel, sheep, goat, and water buffalo meat in Fars and Khuzestan provinces, Iran. Vet. Res. Forum, 3 (1): 13-17.

Saeedi, P.; Yazdanparast, M.; Behzadi, E.; Salmanian, A.; Mousavi, S.; Nazarian, S. and Amani, J. (2017): A review on strategies for decreasing E. coli O157:H7 risk in animals. Microb. Pathog., 103: 186195.

Sambrook, J.; Fritscgh, E. F. and Mentiates (1989): Molecular coloning. A laboratory manual, Cold spring Harbor Laboratotry press, NY. USA.

Sanchez, S.; Martınez, R.; Garcia, A.; Vidal, D.; Blanco, J.; Blanco, M.; Blanco, J. E.; Mora, A.; Herrera-Leon, S.; Echeita, A.; Alonso, J. M. and Rey, J. (2010): Detection and characterisation of O157:H7 and non-O157 Shiga toxin-producing Escherichia coli in wild boars. Vet. Microbiol., 143: 420-423.

Scherrer, D.; Coti, S.; Muehlberr, J. E.; Zweife, C. and Stephan, R. (2004): Phenotypic and genotypic characteristics of $S$. aureus isolates from raw bulk-tank milk samples. Vet. Microbiol., 101:101-107.

Shetty, V. A.; Kumar, S. H.; Shetty, A. K.; Karunasagar, I. and Karunasagar, I. (2012): Prevalence and Characterization of Diarrheagenic Escherichia coli Isolated from Adults and Children in Mangalore, India. J. Lab. Phys. 4 (1): 24-29.

Singh, A.; Chhabra, D.; Sikrodia, R.; Shukla, S.; Sharda, R. and Audarya, S. (2018): Isolation of $E$. coli from bovine mastitis and their antibiotic sensitivity pattern. Int. J. Curr. Microbiol. App. Sci., 7 (10): 11-18.

Suardana, I. W.; Widiasih, D. A.; Nugroho, W. S.; Wibowo, M. H. and Suyasa, I. N. (2017): Frequency and risk-factors analysis of Escherichia coli O157:H7 in Bali-cattle. Acta Tropica, (172): 223-228.

Tarr, P. I.; Gordon, C. A. and Chandler, W. L. (2005): Shiga-toxin-producing Escherichia coli and haemolytic uraemic syndrome. Lancet, 365: 10731086.

Tzschoppe, M.; Martin, A. and Beutin, L. (2012): A rapid procedure for the detection and isolation of enterohaemorrhagic Escherichia coli (EHEC) serogroup O26, O103, O111, O118, O121, O145 and O157 strains and the aggregative EHEC O104:H4 strain from ready-to-eat vegetables. Int. J. Food Microbiol., 152; 19-30.

Valilis, E.; Ramsey, A.; Sidiq, S. and DuPont, H. L. (2018): Non-O157 Shiga toxin-producing Escherichia coli-A poorly appreciated enteric pathogen: Systematic review. Int. J. Infect. Dis., 76: 82-87.

Fayoum J. Agric. Res. \& Dev., Vol. 33, No.1, January, 2019 
Amr E. M. Mahmoud ${ }^{1}$, et al.,

Wasilenko, J. L.; Fratamico, P. M.; Narang, N.; Tillman, G. E.; Ladely, S.; Simmons, M. and Cray, W.C. (2012): Influence of primer sequences and DNA extraction method on detection of non-O157 Shiga toxinproducing Escherichia coli in ground beef by real time PCR targeting the eae, stx, and serogroup-specific genes. J. Food Prot., 75: 1939-1950.

Watahiki, M.; Isobe, J.; Kimata, K.; Shima, T.; Kanatani, J.; Shimizu, M.; Nagata, A.; Kawakami, K.; Yamada, M.; Izumiya, H.; Iyoda, S.; Morita-Ishihara, T.; Mitobe, J.; Terajima, J.; Ohnishi, M. and Sata, T. (2014): Characterization of enterohemorrhagic Escherichia coli 0111 and 0157 strains isolated from outbreak patients in Japan. J. Clin. Microbiol., 52: 2757-2763.

Watson, V. E.; Jacob, M. E.; Flowers, J. R.; Strong, S. J.; DebRoy, C. and Gookin, J. L. (2017): Association of atypical enteropathogenic Escherichia coli with diarrhea and related mortality in kittens. J. Clin. Microbiol., 55: 2719-2735.

Widiasih, D. A.; Nugroho, W. S.; Wibowo, M. H. and Suyasa, I. N. (2017): Frequency and risk-factors analysis of Escherichia coli O157:H7 in Balicattle. Acta Trop., 172: 223-228.

World Health Organization (2017): Diarrhoeal disease Key facts, Available at: https://www.who.int / news-room / factsheets / detail / diarrhoealdisease. Accessed 20 December 2018.

Yang, S. C.; Lin, C. H.; Aljuffali, I. A.; and Fang, J. Y. (2017): Current pathogenic Escherichia coli foodborne outbreak cases and therapy development. Arch. Microbiol., 199: 811-825.

Fayoum J. Agric. Res. \& Dev., Vol. 33, No.1, January, 2019 


\section{Appendix (1): Vitek2 Gram-negative card well contents according to BioMerieux, manufacturer manual}

\begin{tabular}{|l|l|}
\hline 5KG: 5-Keto-D-Gluconate & GlyA: Glycine arylamidase \\
ADO: Adonitol & $\mathrm{H}_{2} \mathrm{~S}: \mathrm{H}_{2}$ S production \\
AGAL: $\alpha$-galactosidase & IARL: L-arbitol \\
AGLTP: GlutamylArylamidase- & IHISa: L-histidine assimilation \\
transferase & ILATa: L-Lactate assimilation \\
AGLU: $\alpha$-glucosidase & ILATK: L-Lactate assimilation \\
APPA: Ala-Phe-Pro-Arylamidase & IMLTa: L-Malate assimilation \\
BAlap: $\beta$-Alanine arylamidasepNA & LDC: Lysine decarboxylase \\
BGAL: $\beta$ - Galactosidase & LIP: Lipase \\
BGLU: $\beta$-Glucosidase & MNT: Malonate \\
BGUR: $\beta$-glucuronidasE & NAGA: $\beta$-N-Acetyl-Galactosaminidase \\
BNAG: $\beta$-N-Acetyl-Glucoaminidase & O129R: 0/129 resistance (comp.vibrio) \\
BXYL: $\beta$-Xylosidase & ODC: Ornithine decarboxylase \\
CIT: Sodium Citrate & OFF: Fermentation Glucose \\
CMT: Coumerate & PHOS: Phosphate \\
dCEL: D-cellobiose & PLE: Palatinose \\
dGLU: D-glucose & proA: L-ProlineArylamidase \\
dMAL: D-maltose & PyrA: L-Pyrrolydonyl-Arylamidase \\
dMAN: D-mannitol & SAC: Saccharose/Sucrose \\
dMNE: D-mannose & SUCT: Succinate alkalinization \\
dSOR: D-Sorbitol & TyrA: Tyrosine Arylamidase \\
dTAG: D-Tagatose & URE: Urease \\
dTER: D-Trehalose & STAG: D-Tagatose \\
ELLM: Ellman & \\
GGT: $\gamma$-Gutamyl- Transferase & \\
\hline
\end{tabular}

Fayoum J. Agric. Res. \& Dev., Vol. 33, No.1, January, 2019 


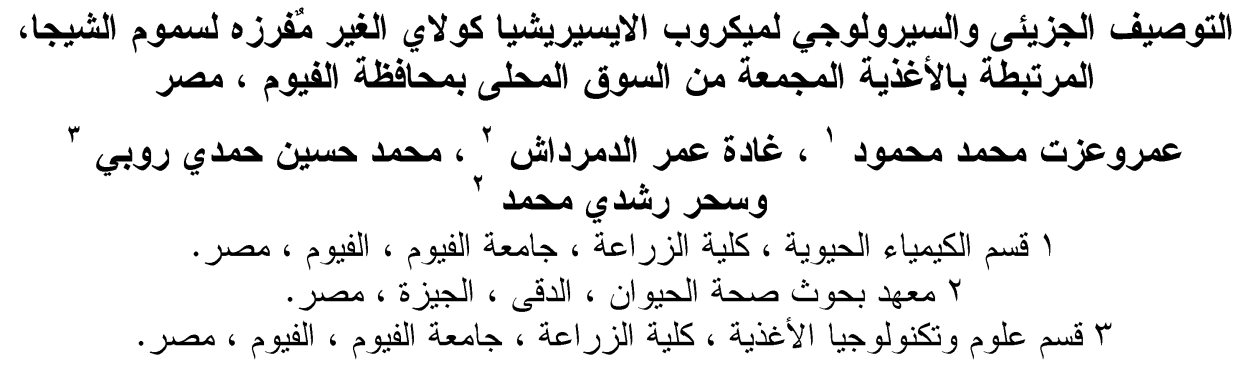

تعتبر الايسيريشيا كو لاي واحدة من البكنيريا التي تسبب تفشي الإسهال في جميع أنحاء

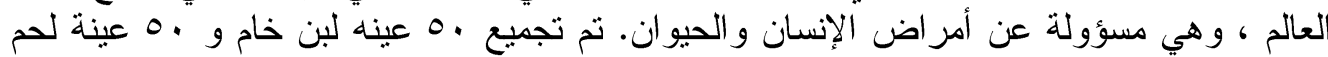

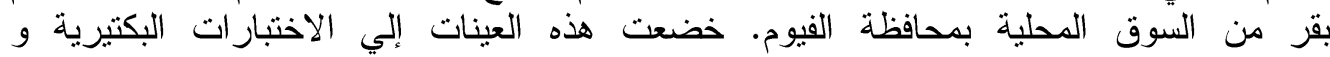

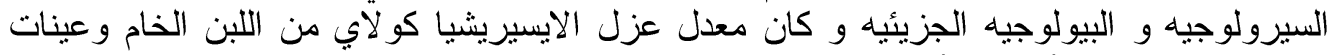

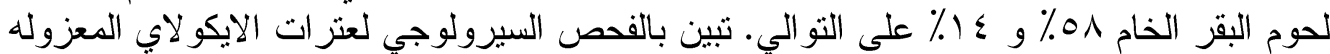

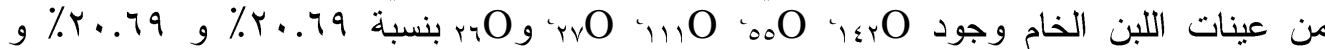

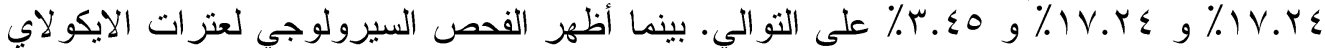

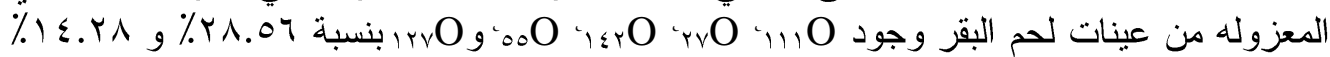

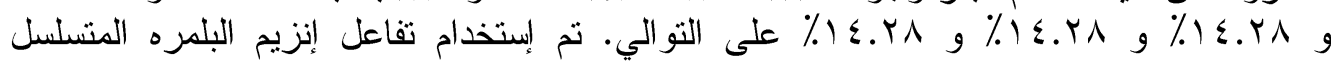
لاكتشاف جينات الضراوة لكل من stx1 - stx2 (PCR)

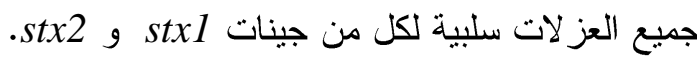

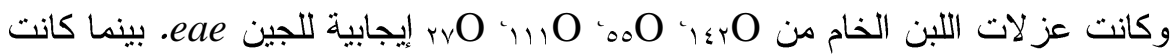

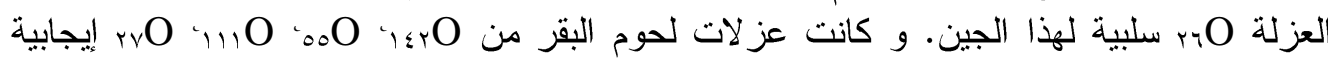

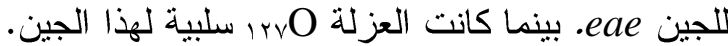

Fayoum J. Agric. Res. \& Dev., Vol. 33, No.1, January, 2019 